\title{
Viable versus inactivated lactobacillus strain GG in acute rotavirus diarrhoea
}

\author{
Minna Kaila, Erika Isolauri, Maija Saxelin, Heikki Arvilommi, Timo Vesikari
}

\begin{abstract}
The effect of viable or heat inactivated human Lactobacillus casei strain GG on rotavirus immune responses in patients with rotavirus diarrhoea was assessed. Rotavirus serum IgA enzyme immunoassay antibody responses were higher in infants treated with viable $L$ case $i$ strain GG than in those treated with inactivated $L$ casei strain GG. There was a significant difference at convalescence with rotavirus specific IgA secreting cells found in 10/12 infants receiving viable but only $2 / 13$ infants receiving inactivated $L$ casei strain GG. The results indicate that viable $L$ case $i$ strain GG stimulate rotavirus specific IgA antibody responses, theoretically significant in the prevention of reinfections.

(Arch Dis Child 1995; 72: 51-53)
\end{abstract}

Keywords: rotavirus, diarrhoea, lactobacillus strain GG, diet.

The treatment of acute diarrhoea begins with correction and maintenance of rehydration, but the appropriate diet thereafter is debated. ${ }^{1}$ It has been suggested that the optimal diet should include fermented milks as they are low in lactose, their proteins are more easily digested, and they seem to have advantageous effects on the immune responses. ${ }^{2}$ In a previous study, the peroral administration of Lactobacillus casei strain GG during acute diarrhoea was associated with an enhanced immune response to rotavirus as measured by circulating IgM and IgA producing cells at the acute stage of the infection. ${ }^{3}$ Using measurement of this immune response as a tool, the present randomised double blind two cell clinical trial was designed to address specifically the question whether viable lactobacilli are required for stimulation of rotavirus specific immune responses.

\section{Patients and methods}

The inclusion criteria were admission for acute gastroenteritis of less than seven days' duration and age less than 4 years. During the period of the rotavirus epidemic season, 41 well nourished children (mean age 12.8 months, range 1.3-38.4) were enrolled.

On admission the children were clinically examined, and their treatment followed the usual clinical guidelines of oral rehydration and rapid refeeding. ${ }^{4}$ The children were weighed daily, and the attending nurses noted the quality (watery, loose, or solid) and number of stools. Together with the rapid refeeding regimen appropriate for age, the patients received in a randomised, double blind fashion twice daily either viable $L$ case $i$ strain GG, $10^{10-11}$ colony forming units (cfu) $(n=20$, group $A)$, or heat inactivated $L$ case $i$ strain GG ( $n=21$, group $B)$, each for five days. The patients were discharged according to the judgment of the attending paediatrician. The patients were seen by a physician (MK), who was blinded to the treatment group, at convalescence one month later.

Twenty six of 41 patients fulfilled the inclusion criteria and were rotavirus positive, therefore the final study population was 13 for group A and 13 for group B.

The preparations of $L$ casei strain GG were manufactured by the Research and Development Centre of Valio Ltd, Helsinki, Finland, as follows. $L$ casei strain GG was concentrated, washed with water, and the concentrate divided into two. One half was heated to $85-100^{\circ} \mathrm{C}$ for $10 \mathrm{~min}$. Saccharose was added as a cryoprotectant into both halves (about $50 \%$ of dry matter), and both preparations were lyophilised. The viable half, that was not heat treated, contained $1 \times 10^{11} \mathrm{cfu} / \mathrm{g}$ $L$ case $i$ strain GG, whereas the heat inactivated half did not contain living bacteria. Both preparations were divided into $0 \cdot 1 \mathrm{~g}$ aliquots and stored at $-18^{\circ} \mathrm{C}$ until reconstitution and administration in tap water (about $5 \mathrm{ml}$ ). The appearance and taste of these solutions were indistinguishable.

Heparinised blood was drawn for the enzyme linked immunospot (ELISPOT) assay during the acute phase (day 1 after admission) ( $n=12$ in group $A, n=11$ in group $B$ ), and at follow up one month later $(n=12$ in group $A$, $\mathrm{n}=13$ in group $\mathrm{B}$ ). During diarrhoea measurement of the rotavirus specific response was possible in nine and eight patients, respectively. For rotavirus antibody studies paired sera were available from 11 patients in group $A$ and six patients in group $B$.

The ELISPOT assays measuring the number of lymphocytes secreting immunoglobulins of isotypes $\operatorname{IgM}, \operatorname{IgA}$, and $\operatorname{IgG}$ (immunoglobulin secreting cells) and the number of lymphocytes secreting specific antibodies to rotavirus (specific antibody secreting cells) were carried out as described previously. $^{3}$

Rotavirus IgA and IgG serum antibodies were measured using an enzyme linked immunosorbent assay (ELISA) method, which was a single serum dilution modification of the test described by Midthun et al. ${ }^{5}$ The antigen was a rhesus human reassortant rotavirus strain $\mathrm{D} \times \mathrm{RRV}$ (a reassortant between $\mathrm{D}$ 
Table 1 Clinical description of the patients receiving viable (group A) or inactivated (group B) L casei strain GG on admission and on discharge; data are mean (SD)

\begin{tabular}{|c|c|c|c|}
\hline & Group $A(n=13)$ & Group $B(n=13)$ & p Value ${ }^{\star}$ \\
\hline $\begin{array}{l}\text { On admission } \\
\text { Age (months) } \\
\text { Duration of diarrhoea (days) } \\
\text { Weight (g) } \\
\text { Weight loss (g) } \\
\text { Serum sodium (mmol/l) } \\
\text { pH }\end{array}$ & $\begin{array}{l}12 \cdot 7(4 \cdot 8) \\
2 \cdot 5(1 \cdot 4) \\
9750(2340) \\
373(123) \\
137(5) \\
7 \cdot 35(0 \cdot 06)\end{array}$ & $\begin{array}{c}16 \cdot 2(8 \cdot 5) \\
2 \cdot 9(2 \cdot 0) \\
10130(2040) \\
472(218) \\
138(5) \\
7 \cdot 35(0 \cdot 07)\end{array}$ & $\begin{array}{l}0.21 \\
0.53 \\
0.66 \\
0.15 \\
0.56 \\
0.88\end{array}$ \\
\hline $\begin{array}{l}\text { On discharge } \\
\text { Weight }(\mathrm{g}) \\
\text { Mean }(95 \% \mathrm{CI}) \text { duration of diarrhoea } \\
\text { (days) }\end{array}$ & $\begin{array}{l}9870(2100) \\
1.5(1.0 \text { to } 2 \cdot 2)\end{array}$ & $10450(2100)$ & $0 \cdot 51$ \\
\hline
\end{tabular}

«Student's $t$ test.

strain human rotavirus and rhesus rotavirus (RRV)) grown in MA-104 cells; this virus has the VP7 serotype specificity of human rotavirus serotype 1 . Briefly, microtitre plates were coated with hyperimmune rabbit antirotavirus serum (Dakopatts $\mathrm{a} / \mathrm{s}$ ) and subsequently with the supernatant of $D \times R R V$ infected MA-104 cell culture. The plates were blocked with $5 \%$ fetal bovine serum dilutions in phosphate buffer Tween. Single serum dilutions (1:50) were placed in duplicate wells. Alkaline phosphatase conjugated rabbit IgG to human $\alpha$-chain and $\gamma$-chain (for IgA and IgG, respectively) followed by $p$-nitrophenyl phosphate substrate were added, and the absorbance read at $405 \mathrm{~nm}$. Known positive and negative control sera were included. The results were expressed in enzyme immune units after comparison with positive and negative control sera. The value of a given serum was its percentage of the absorbance value of the positive reference serum corrected by background.

Rotavirus in stools was tested with an enzyme immunoassay (Rotazyme, Abbott Laboratories).

\section{STATISTICAL ANALYSES}

Because of skewed distribution of data natural logarithmic transformation was used, and the results are given as geometric means (95\% confidence interval, CI). The Student's two tailed independent $t$ test was used as appropriate. The $\chi^{2}$ test was used in statistical comparisons.

\section{Results}

\section{CLINICAL OUTCOME}

The clinical characteristics on admission were consistent with mild to moderate dehydration and metabolic acidosis and did not differ between groups. The duration of diarrhoea after admission was short in both groups, and

Table 2 Number of patients showing a rotavirus specific IgA specific antibody secreting cell response, and the level of rotavirus specific IgA serum antibodies at the acute and convalescent stage of rotavirus gastroenteritis, in infants receiving viable (group $A$ ) or inactivated (group B) L casei strain $G G$

\begin{tabular}{|c|c|c|c|}
\hline & Group $A$ & Group B & p Value \\
\hline \multicolumn{4}{|c|}{ Specific antibody secreting cells (No with $>0 \cdot 5 / 10^{6}$ cells $/$ No of patients) } \\
\hline Acute & $2 / 9$ & $2 / 8$ & $0 \cdot 66^{\star}$ \\
\hline Convalescent & $10 / 12$ & $2 / 13$ & $0.002^{\star}$ \\
\hline \multicolumn{4}{|c|}{ Mean $(95 \% \mathrm{CI})$ antibodies (EIU) } \\
\hline Acute & $0.04(0.01$ to 0.3$)$ & $0.1(0.01$ to 0.5$)$ & $0.52 \dagger$ \\
\hline Convalescent & $50 \cdot 7(29 \cdot 4$ to $87 \cdot 2)$ & $22.4(11.7$ to 43.0$)$ & $0.04 \dagger$ \\
\hline
\end{tabular}

«The $\chi^{2}$ test; $†$ Student's $t$ test. EIU $=$ enzyme immune units. there was no difference between the patients receiving viable and inactivated $L$ case $i$ strain GG (table 1).

\section{IMMUNOLOGICAL OUTCOME}

At the acute stage, the concentrations of immunoglobulin secreting cells of isotypes IgM, IgA, and IgG were high in both treatment groups. There was a tendency to a greater response in group A than in group B, although the difference was not statistically significant. The transient nature of this response was demonstrated by a significant decrease in the number of immunoglobulin secreting cells by convalescence compared with values during diarrhoea; the two treatment groups were alike (data not shown).

During diarrhoea, the mean numbers of specific antibody secreting cells to rotavirus $/ 10^{6}$ cells were similar in both groups (data not shown). The IgM and IgG specific antibody secreting cells to rotavirus could not be detected at convalescence in either treatment group.

Very low numbers of IgA secreting cells to rotavirus were seen during diarrhoea in both treatment groups alike. By convalescence, there was a $5 \cdot 4$-fold increase in the number of these cells in group A compared with group B, with a risk ratio of $5.4(95 \%$ CI from 1.5 to 19.9). Most patients in group A, but not in group $\mathbf{B}$, showed a detectable rotavirus specific antibody secreting cells response at the convalescent stage.

All patients had a detectable ELISA IgA response to rotavirus from the acute to the convalescent stage (table 2). The mean IgA antibody concentrations at the acute stage were low, and similar in the two groups. The infants in group A showed a more vigorous IgA serum antibody response to rotavirus and had higher antibody values at convalescence than infants in group $B$.

\section{Discussion}

A recent study showed that even in infants under the age of 6 months, a previously tolerated milk can safely be included in the diet during acute diarrhoea. ${ }^{6}$ Moreover, milk fermented with lactic acid bacteria has been shown to shorten the duration of acute diarrhoea. ${ }^{3}$ The usefulness of such milks in the diet during diarrhoea can be linked with viability of the lactic acid bacteria, and therefore their ability to survive the gut transit, to adhere to the mucosa, and transiently to colonise the gut. The adherent property is significant in enhancing the local immune response, and in stabilising the mucosal barrier to decrease inadvertent transmission of antigens from the gut. ${ }^{78}$ In contrast to the alleged importance of viability, immunostimulation and a beneficial clinical effect have also been demonstrated using a supernatant obtained after centrifugation of lactic acid bacteria. $^{9}$

The most interesting result of the present study is that viable $L$ case $i$ strain GG enhanced 
the rotavirus specific IgA secreting cell response and the serum $\operatorname{IgA}$ antibody response to rotavirus. Therefore, using viable $L$ casei strain GG as an adjunct in the diet during acute rotavirus diarrhoea may promote development of immunity against reinfections. ${ }^{10}$ In this study, clinical recovery from rotavirus diarrhoea was equal in the two groups receiving viable or heat inactivated $L$ casei strain GG during the diarrhoea. However, in developing countries using heat inactivated $L$ case $i$ strain GG might obviate the need to preserve viability of the bacteria, while maintaining the beneficial clinical effect.

The Foundation for Nutrition Research, Finland, is gratefully acknowledged for financial support.

1 Walker-Smith JA. Management of infantile gastroenteritis.

Arch Dis Child 1990; 65: 917-8.
2 Bourlioux P, Pochart P. Nutritional and health properties of yogurt. World Rev Nutr Diet 1988; 56: 217-58.

3 Kaila M, Isolauri E, Soppi E, Virtanen E, Laine S,
Arvilommi H. Enhancement of the circulating antibody secreting cell response in human diarrhea by a human lactobacillus strain. Pediatr Res 1992; 32: 141-4.

4 Isolauri E, Vesikari T, Saha P, Viander M. Milk versus no milk in rapid refeeding after acute gastroenteritis. $\mathcal{f}$ Pediatr Gastroenterol Nutr 1986; 5: 254-61.

5 Midthun K, Pang L, Flores J, Kapikian AZ. Comparison of immunglobulin A, IgG, and IgM enzyme-linked immunosorbent assays, plaque reduction neutralization assay, and complement fixation in detected seroresponses to rotavirus vaccine candidates. $\mathcal{F}$ Clin Microbiol 1989; 27: 2799-804.

6 Chew F, Penna FJ, Peret Filho LA, et al. Is dilution of cows' milk formula necessary for dietary management of acute diarrhoea in infants aged less than 6 months? Lancet 1993; 341: 194-7.

7 Van der Heiden P, Bianchi ATH, Dol M, Pals JW, Stok W, Bokhout BA. Manipulation of the intestinal immune responses against ovalbumin by cholera toxin and its $B$ subunit in mice. Immunology 1991; 72: 89-93.

8 Isolauri E, Kaila M, Arvola T, et al. Diet during rotavirus enteritis affects jejunal permeability to macromolecules in suckling rats. Pediatr Res 1993; 33: 548-53.

9 Perdigon G, de Macias MEN, Alvarez S, Oliver G, de RuizHolgado AP. Systemic augmentation of the immune response in mice by feeding fermented milks with Lactobacillus casei and Lactobacillus acidophilus. Immunology 1988; 63: 17-23.

10 Uhnoo I, Dharakul T, Riepenhoff-Talty M, Ogra PL Festschrift: immunological aspects of interaction between rotavirus and the intestine in infancy. Immunol Cell Biol 1988; 66: 135-45. 